\title{
Antioxidant Activity and Total Phenolic/Flavonoid Contents of Phlomis pungens $L$.
}

\section{Phlomis pungens L.'nin Antioksidan Aktivitesi ve Toplam Fenolik/Flavonoid Iç̧eriği}

\author{
Research Article
}

\author{
Mesut Işık', Emrah Dikici², Hatice Tohma ${ }^{3 *}$, Ekrem Köksal ${ }^{3}$ \\ ${ }^{1}$ Harran University, Department of Medical Services and Techniques, Health Services Vocational School, Şanlıurfa, Turkey. \\ ${ }^{2}$ Aksaray University, Central Laboratory, Department of Chemistry, Aksaray, Turkey. \\ ${ }^{3}$ Erzincan University, Faculty of Science, Department of Chemistry, Erzincan, Turkey.
}

\section{A B STR ACT}

0 lants generate secondary metabolites, which could be used as novel therapeutic compounds. These compounds are well known for their beneficial effects on human health. Thus, it is important to evaluate total phenolic and flavonoid contents as well as antioxidant activities of different plants. The present study was conducted to determine the total phenolic/flavonoid content and antioxidant activity of ethanol extract prepared from leaves of Phlomis pungens L. The total phenolic content of the ethanol extract of the sample were determined using the Folin-Ciocalteu reagent. Antioxidant activity of Phlomis pungens L. was determined using different in vitro experimental models, which include DPPH, FRAP, CUPRAC and potassium thiocyanate method. Total phenolic and flavonoid contents of Phlomis pungens L. were found to be $68.4 \mathrm{mg} \mathrm{GAE} / \mathrm{g}$ and $4.9 \mathrm{mg} \mathrm{QE} / \mathrm{g}$, respectively. Antioxidant activity of the sample was comparable to commercial antioxidant standards (BHT, - tocopherol and trolox). The results showed that Phlomis pungens $L$ has moderate free radical scavenging and reducing capacity. Overall, this study discovers total phenolic and flavonoid content as well as antioxidant properties of Phlomis pungens L

\section{Key Words}

Phlomis pungens L. antioxidant activity, oxidative stress.

\section{öz}

itkiler terapötik bileşikler olarak kullanılabilen ikincil metabolitleri üretirler. Bu bileşikler, insan sağlığı üzerindeki olumlu etkileri açısından iyi bilinmektedir. Bu nedenle farklı bitkilerin antioksidan aktivitelerinin yanı sıra toplam fenolik ve flavonoid içeriğinin değerlendirilmesi önemlidir. Bu çalışma Phlomis pungens L.'nin yapraklarından hazırlanan etanol özütünün toplam fenolik/flavonoid içeriğini ve antioksidan aktivitesini belirlemek amacıyla yürütülmüştür. Numunenin etanol özütünün toplam fenolik içeriği Folin-Ciocalteu reaktifi kullanılarak belirlendi. Phlomis pungens L.'nin antioksidan aktivitesi, DPPH, FRAP, CUPRAC ve potasyum tiyosiyanat yönteminin içeren farklı in vitro deneysel modeller kullanılarak belirlendi. Phlomis pungens L.'nin toplam fenolik ve flavonoid içeriği sırasıyla $68.4 \mathrm{mg} \mathrm{GAE} / \mathrm{g}$ ve $4.9 \mathrm{mg} \mathrm{QE} / \mathrm{g}$ olarak bulundu. Numunenin antioksidan aktivitesi, ticari antioksidan standartlarıyla (BHT, $\alpha$-tokoferol ve trolox) kıyaslandı. Sonuçlar, Phlomis pungens L'nin orta düzeyde serbest radikal süpürme ve indirgeme Me kapasitesine sahip olduğunu gösterdi. Genel olarak, bu çalışma Phlomis pungens L'nin antioksidan özelliklerinin yanı sıra toplam fenolik ve flavonoid içeriğini ortaya çıkarmıştır.

\section{Anahtar Kelimeler}

Phlomis pungens L., antioksidan aktivite, oksidatif stres.

Article History: Received: Mar 17, 2017; Revised: Jul 19, 2017; Accepted: Oct 9, 2017; Available Online: Dec 25, 2017. DOI: 10.15671/HJBC.2018.184

Correspondence to: H. Tohma, Erzincan University, Faculty of Science, Department of Chemistry, Erzincan, Turkey. 


\section{INTRODUCTION}

A free radical is a molecule or molecular fragment, which consist an unpaired electron in the valence shell [1]. The physiological importance of free radicals have been recognized by the discovery of superoxide dismutase enzyme [2], which removes oxygen-centered radical occurring as a result of incomplete reduction. Later studies revealed that over production or insufficient removal of radicals results in a state called oxidative stress, wherein oxidation of macromolecules (proteins, lipids, nucleic acids) starts to accumulate over the course of time [3]. Oxidative stress appears to be rising in many pathological conditions, including heart diseases [4], cancer [5], diabetes [6] and metabolic syndrome. In this scenario, it has been suggested that unremoved free radicals cause the oxidation of cellular components leading to permanent loss of their function [7]. Therefore, dietary supplementation of antioxidants could be a powerful strategy to reduce free radical related damage and, consequently, the likelihood of occurrence of serious health problems [8].

The recognition of that plant extract have beneficial effects on human health has led to an increased attention on phytochemicals, mainly phenols and flavonoids, as well as their function and properties. One of the ways that phytochemicals promote health and prevent diseases could be through their effects as antioxidants. For example, green tea extract (GTE) was found to prevent Angiotensin (Ang) II induced endothelial dysfunction and possible mechanism was proposed to be the prevention or scavenging of superoxide anion generation [9]. Furthermore, a recent study has found that black tea Camellia sinensis (BTE) extract has cytotoxic effects against human colon carcinoma cell line HT-29, human breast carcinoma cell line MCF-7, human alveolar carcinoma cell line A549 [10]. In addition, a medicinal plant Yucca schidigera, which is a rich in polyphenolics, was found to have antiinflammatory activity by suppressing reactive oxygen species formation [11]. All these studies strength the idea that the beneficial effects of plants rich in phenolic substance could be due to their antioxidant characteristics.
Besides having used as dietary supplements to promote health, antioxidants also have commercial value since they can be used to preserve food and nutritionally enhance the food properties. Although synthestic antioxidants such as 2- and 3-tert-butyl-4-methoxyphenol (i.e. butylated hydroxyanisole, BHA), 2,6-di-tert-butyl4-methylphenol (i.e. butylated hydroxytoluene, $\mathrm{BHT}$ ) and tert-butylhydroquinone (TBHQ) have been used as food additives, this safety has been questioned due to their toxic effects [12]. Therefore, the need for antioxidants from botanical sources have increased. Crude extract of plants, herbs and species which are rich in polyphenolics are capable of retarding lipid peroxidantion and improving nutritional value of foods [13].

Phlomis is a genus belongs to the family Lamiaceae, consisting more than 100 species growing in Turkey, North Africa, Europe and Asia [14]. Various studies indicated the medicinal value of Phlomis, which are claimed to be effective to promote good health protecting the liver, kidney, bone and cardiovascular system [14]. Antiulcerogenic [15], antimicrobial [16], anti-allergic [17], and antioxidant properties of Phlomis species [18] have also been documented. Morever, among 16 different plant species, ethanolic extract of $P$. pungens showed the higest antibacterial activity against $S$. pyogenes [19]. In addition, three species of Phlomis, namely P. olivieri, $P$. anisodonta and $P$. persica have been reported to exhibit antinociceptive effects comparibe to a reference drug, indomethacin [20]. The main constituents reported for Phlomis species are monoterpenoids, sesquiterpenoids, diterpenoids, triterpenoids, triterpene saponins, flavonoids, lignans, and essential oils $[14,21,22]$

Phlomis pungens $\mathrm{L}$. is a medicinal plant growing in Turkey [19]. however its antioxidant potential and total phenolic/flavonoid content have not been previously reported. Therefore our aim in this study was to estimate total phenolic/flavonoid constituents and evaluate antioxidant characteristic of Phlomis pungens L. using four different assays namely DPPH, FRAP, 
CUPRAC and total antioxidant activity assay by ferric thiocyanate method.

\section{MATERIALS and METHODS}

\section{Chemicals}

DPPH (1,1-diphenyl-2-picryl-hydrazyl), DMPD (N,N-dimethyl-pphenylenediamine), neocuproine (2,9-dimethyl-1,10- phenanthroline), $\alpha$-tocopherol were obtained from Sigma (SigmaAldrich $\mathrm{GmbH}$, Sternheim, Germany). The other chemicals were obtained from Merck.

\section{Plant Materials and the Preparation of Sample Extract}

Plant sample was collected in the village called Sarıgüney-Bozköy, Çayırlı, Erzincan. The plant identity was confirmed by associated Professor Mustafa Korkmaz, Erzincan University. The leaves of the sample was dried in room temperature in the shade. The stems were removed and sample powder was prepared by grounding in pastel with mortar until fine powder was obtained. A $20 \mathrm{~g}$ of sample powder was mixed with $400 \mathrm{ml}$ ethanol on a magnetic stirrer for 24 hour at room temperature. Ethanolic extract was filtered and the mixture is then placed on the rotary evaporator (RE 100 Bibby, Stone Staffordshire England) at $30^{\circ} \mathrm{C}$ to remove ethanol. The sample was stored at $-20^{\circ} \mathrm{C}$ until the experimental procedure.

\section{Determination of Total Phenolic Content by Folin Ciocalteau Assay}

The total phenolic content in Phlomis pungens L. is estimated by a colorimetric assay based on previously described procedure [23] with slight modification [24]. The sample test $(1 \mathrm{mg})$ was taken into a test tube and the final volume is increased to $23 \mathrm{ml}$ with distilled water. 3 minutes later FolinCiocalteu's reagent $(0.5 \mathrm{~mL})$ and $2 \%$ $\mathrm{Na}_{2} \mathrm{CO}_{3}(1.5 \mathrm{~mL})(1.5 \mathrm{~mL})$ were added. The samples are vortexed and then kept at room temperature for 30 minutes. The absorbance measurements are recorded at $760 \mathrm{~nm}$. The distilled water is used either as blank or for control instead of sample. Gallic acid was used as standard phenolic compound and calculation was made on the basis of a standard curve of gallic acid. The absorbance measurements of samples that contain 100, 200, 300,400 and $500 \mu \mathrm{g}$ gallic acid are recorded and standard gallic acid graph was drawn. The results are reported as $\mu \mathrm{g}$ gallic acid equivalents per $\mathrm{mg}$ extract.

\section{Determination of Total Flavonoid Content}

Flavonoids are the most common group of polyphenolic compounds in the human diet and are found ubiquitously in plants [25]. The total flavonoid content in EEGR is estimated by a colorimetric assay based on the procedure described with slight modifications. One $\mathrm{mg}$ of the sample is added into a test tube. Then $0.1 \mathrm{~mL}$ $\mathrm{CH}_{3} \mathrm{COOK}(1 \mathrm{~m})$ and $0.1 \mathrm{~mL}$ of $10 \% \mathrm{Al}\left(\mathrm{NO}_{3}\right)_{3}$ in 4,3 $\mathrm{mL}$ ethanol solution is added and the samples were vortexed, then kept at room temperature for 40 minutes. The absorbance measurements were recorded at $415 \mathrm{~nm}$. The distilled water was used either as blank or for control instead of sample. As a standard, quercetin was used. The absorbance measurements of standard that contain $20,40,60,80$ and $100 \mu$ quercetin were recorded and then the graph was drawn. The results were reported as $\mu \mathrm{g}$ quercetin equivalents per mg extract.

\section{DPPH Scavenging Activity}

Free radical scavenging activity of Phlomis pungens $L$ was determined by DPPH radical scavenging activity, a method of Blois [26]. DPPH is stable free radical with deep purple color. Reaction of DPPH radical with other radicals, electron or hydrogen atoms results in loss of color which could be monitored at $517 \mathrm{~nm}$ [26]. Briefly, sample different concentration of the sample $(10-20-30 \mu \mathrm{g} / \mathrm{mL})$ were taken into the test tube and final volumes were adjusted to $3 \mathrm{ml}$ with ethanol. Then $1 \mathrm{ml}$ of ethanolic DPPH solution $(0.1 \mathrm{mM})$ prepared on daily basis was added to test tubes. After vortexing, sample were incubated in the dark at room temperature for 30 minutes. Decolorization of the DPPH solution was monitored by measuring absorbance at $517 \mathrm{~nm}$ against blank.

\section{Ferric Cyanide $\left(\mathrm{Fe}^{3+}\right)$ Reducing Antioxidant Power Assay (FRAP)}

Reducing ability of the sample was measured by FRAP method according to the method of Oyaizu [27]. The principle of the method is based on the reduction of ferric tripyridyl triazene ( $\left.\mathrm{Fe}^{3+}-\mathrm{TPTZ}\right)$ 
complex to the Prussian blue the ferrous $\left(\mathrm{Fe}^{2+}\right)$ tripyridyl triazene ( $\left.\mathrm{Fe}^{3+}-\mathrm{TPTZ}\right)$ complex, which gives absorbance at $700 \mathrm{~nm}$. Briefly sample at different concentrations in $1 \mathrm{ml}$ water was mixed with phosphate buffer $(2.5 \mathrm{~mL}, 0.2 \mathrm{M}, \mathrm{pH} 6.6)$ and potassium ferricyanide $\left[\mathrm{K}_{3} \mathrm{Fe}(\mathrm{CN})_{6}\right](2.5 \mathrm{~mL}, 1 \%)$ respectively. after incubation at $50^{\circ} \mathrm{C}$ for $20 \mathrm{~min}$. $2.5 \mathrm{~mL}$ trichloroacetic acid (10\%) and $0.5 \mathrm{~mL}$ of $\mathrm{FeCl}_{3}(0.1 \%)$ were added to the test tubes. The absorbance at $700 \mathrm{~nm}$ were measured. Increase in the absorbance of the sample with increasing concentration is the indication of reducing potential of the sample [28].

\section{Cupric lons Reducing Assay (CUPRAC)}

A second method performed to measure the reducing capacity of the sample was $\mathrm{Cu}^{2+}$ reducing power assay (CUPRAC) as previously described [29]. Briefly, the reaction mixture consisting $0.25 \mathrm{~mL}$ of $\mathrm{CuCl}_{2}$ solution $(0.01 \mathrm{M}), 0.25 \mathrm{~mL}$ of ethanolic neocuproine solution $\left(7.5 \times 10^{-3} \mathrm{M}\right)$ and $0.25 \mathrm{~mL}$ of $\mathrm{CH}_{3} \mathrm{COONH}_{4}$ buffer solution (1 M) were mixed and sample at different concentration (10 $20-30 \mu \mathrm{g} / \mathrm{mL}$ ) was added to this mixture. The final volume was adjusted to $2 \mathrm{ml}$ with distilled water. The tubes were mixed well and incubated at room temperature for 30 minutes. Absorbance values were read at $450 \mathrm{~nm}$ against blank. An increase in the absorbance indicates reduction capability. Total antioxidant activity determination by ferric thiocyanate method

The antioxidant activity of Phlomis pungens $L$ was determined according to the ferric thiocyanate method (FTC) as previously described [30]. In this method, peroxidase formed as a result of linoleic acid oxidation oxidiase $\mathrm{Fe}^{2+}$ to $\mathrm{Fe}^{3+}$ and former ion react with thiocyanate to form a complex which give absorbance at $500 \mathrm{~nm}$.

The stock solution was prepared by dissolving $10 \mathrm{mg}$ of sample in $10 \mathrm{ml}$ distilled water. A $20 \mu \mathrm{g} /$ $\mathrm{mL}$ concentration of antioxidant samples in $2.5 \mathrm{~mL}$ of potassium phosphate buffer $(0.04 \mathrm{M}, \mathrm{pH}$ 7.0) was mixed with $2.5 \mathrm{~mL}$ of linoleic acid emulsion in potassium phosphate buffer solution $\left(0.04 \mathrm{M}_{\text {, }}\right.$ $\mathrm{pH}$ 7.0). During the incubation at $37^{\circ} \mathrm{C}$, a $0.1 \mathrm{~mL}$ aliquot of the mixture is diluted with $3.7 \mathrm{~mL}$ of ethanol, and then it was added to the mixture of $0.1 \mathrm{~mL}$ of ammonium thiocyanate (30\%) and 0.1
$\mathrm{mL}$ of ferrous chloride $(20 \mathrm{mM})$ in hydrochloric acid (3.5\%). The level of the complex from between $\mathrm{Fe}^{3+}$ and thiocyanate was measured at $500 \mathrm{~nm}$ at every 6 hours until the control reached its maximum level. The amounts of inhibition was alculated by the following equation:

Inhibition of lipid proxidaition $(\%)=100-\left(A_{s} / A_{c} \times 100\right)$

\section{RESULT and DISCUSSION}

\section{Total Phenolic and Flavonoid Content}

Using the standard curve of gallic acid, total phenolic content of Phlomis pungens was found to be $68.4 \mathrm{GAE} \mu \mathrm{g} / \mathrm{mL}^{-1}$. Using the standard curve generated using quercetin, the total flavonoid content of Phlomis pungens was found to be 4.9 $\mu \mathrm{g} \mathrm{QE} / \mathrm{mL}$.

A previous study showed that Phlomis thapsoides contained $362.06 \mathrm{mg}$ of gallic acid equivalents [31]. In addition Ethyl acetate, methanol and water extract of Phlomis armeniaca contained 41.9, 55.2 and $54.4 \mathrm{mg} \mathrm{GAEs/g}$ extract, respectively [32]. The major phenolic compounds reported for two Phlomis species ( $P$. umbrosa and $P$. megalantha) were gallic acid, protocatechic acid, chlorogenic acid, vanillic acid, caffeic acid, $\mathrm{p}$-coumaric acid, ferulic acid, benzoic acid, salicylic acid, rosmarinic acid, cinnamic acid, (+)-catechin, (-)-epicatechin, and rutin [33]. There are some reports on total flavonoid of different Phlomis species. For example it has been found that methanol extract of Phlomis nissolii L. contained $54.6 \mathrm{mg}$ rutin equivalents $/ \mathrm{g}$ extract [34]. Moreover, total flavonoid content of acetone and methanol extract of $P$. umbrosae were 12.1 and $17.1 \mathrm{~g} \mathrm{EE} / \mathrm{g}$ extract, respectively [33]. The major flavonoids reported for Phlomis genus are apigenin, luteolin naringenin, eriodictyol, chryseriol, kaempferol and their glycosides [14].

\section{Antioxidant Assays}

Some of the ways in which the activity of an antioxidant is determined are a) free radical scavenging activity, which relates to its reduction potential b) metal chelating activity and c) inhibition activity in free radical chain reactions. 
It is well known that a single antioxidant activity assay is not always sufficient to measure antioxidant capacity of a product. Therefore, it is advised to utilize different types of antioxidant assays to have better understanding of the sample studied. In this work we performed 1,1-diphenyl-2-picrylhydrazyl (DPPH), ferricreducing/antioxidant power (FRAP) and cupric reducing antioxidant capacity (CUPRAC)] as well as total antioxidant activity determination by ferric thiocyanate method.

\section{Radical Scavenging Activity}

Many diseases have been associated with increased incidence of oxidative stress $[35,36]$, where in production of free radicals overwhelms their removal leading to oxidation of vital biomacromolecules such as proteins, lipids and nucleic acids [37]. However, there are numerous studies showing the connection between the intake of food rich in antioxidants and reduced risk of oxidative stress related conditions such as myocardial ischemia-reperfusion injury [38] and certain type of cancers $[39,40]$. Studies on antioxidants have revealed that the health promoting effect of plant-based sources could be derived from phenols and flavonoids contents. These compounds alone or in combination with others may act as anticancer or cardio protective agents via various mechanisms.

Radical scavenging activity of a product is extremely important, since in physiological conditions, generated free radicals are able to oxidase, for example, lipids leading to deleterious changes in the structure of the macromolecules. In order to measure free radical scavenging activity of the sample, DPPH method has been widely performed, since it is fast, simple and sensitive enough to measure radical scavenging activity even at low concentrations [41]. In principle, antioxidant converts the purple chromogen DPPH• radical which to 1,1-diphenyl-2-picryl hydrazine and decoloriazation of DPPH after the reaction with sample mixture could be measured at 517 $\mathrm{nm}$ [42]. The scavenging effect of the sample is shown in Figure 1. For the comparison purpose, standard antioxidants (BHT, $\alpha$-tocopherol and trolox) have been used as reference antioxidants. The result showed that ethanol extract of the

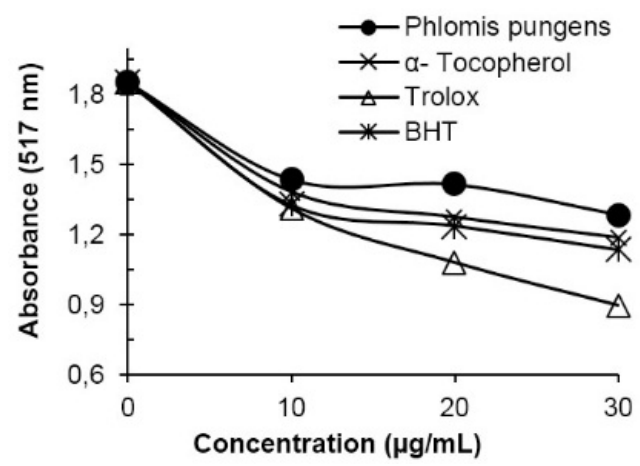

Figure 1. DPPH free radical scavenging activity of different concentrations $(10-30 \mu \mathrm{g} / \mathrm{mL})$ of Phlomis pungens and reference antioxidants; BHT, $\alpha$-tocopherol and trolox (BHT: butylated hydroxytoluene; DPPH : $\alpha, \alpha$-diphenyl- $\beta$ picryl-hydrazyl free radical).

sample is able to scavenge DPPH• radical even at low concentration $(10 \mu \mathrm{g} / \mathrm{L})$. However increases in the concentration did not lead a further reduction in the absorbance. Among the standards, trolox was the most effective antioxidant to remove $\mathrm{DPPH} \bullet$ in a concentration dependent manner.

The factors affecting the antioxidant activity of a compound is the extraction solution of the sample and free radical used in the method. For example, free radical scavenging activity of Phlomis armeniaca was investigated using three different solvents and four different radical namely, DPPH radical, ABTS radical cation, superoxide anion radical, nitric oxide radical. In the study it was reported that the sample showed the highest radical scavenging potential in the water extract using DPPH assay $(125.23 \pm 1.08 \mathrm{mg}$ TEs/g extract) and in the methanol extract using ABTS assay (146.81 $\pm 0.17 \mathrm{mg} \mathrm{TEs} / \mathrm{g}$ extract), respectively [32]. A different study also showed that Phlomis nissolii $L$ has a better scavenging activity in the extract of methanol $\left(\mathrm{IC}_{50}: 2.28 \mathrm{mg} / \mathrm{mL}\right)$ and water $\left(\mathrm{IC}_{50}: 1.17\right.$ $\mathrm{mg} / \mathrm{mL})$ than that in ethyl acetate $(12.18 \mathrm{mg} / \mathrm{mL})$. However, consistent with our findings, even these values were significantly lower compared to the value of trolox ( $\mathrm{IC}_{50}: 0.15 \mathrm{mg} / \mathrm{mL}$ ) [34]. Phlomis caucasica was found to have seven major freeradical-scavenging phenolic compounds namely (1), chrysoeriol 7-0-rutinoside (2), kaempferol 3-0-glucoside (3), chrysoeriol 7-0-glucoside (4) and naringenin (5), and two phenylethanoid glycosides, forsythoside B (6) and acteoside (7), last two of which was found to be most potent antioxidants, as measured with DPPH assay [43]. 
A

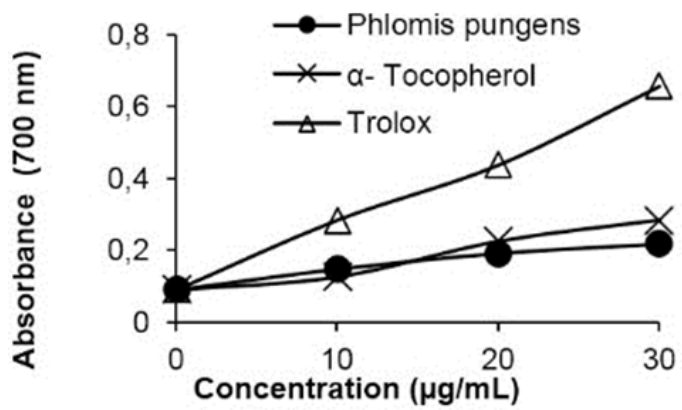

B

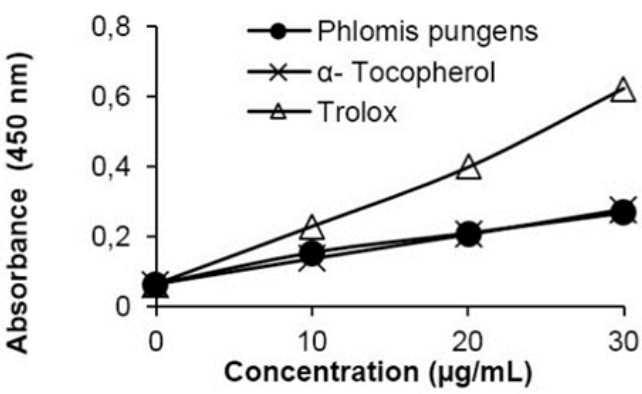

Figure 2. Total reductive potential of different concentrations $(10-30 \mu \mathrm{g} / \mathrm{mL})$ of Phlomis pungens and reference antioxidants determined by (A) FRAP method and (CUPRAC) method.

Furthermore a compound isolated from Phlomis syriaca, namely Chlorogenic acid, has potent radical scavenging activity (68.6\% scavenging) which is almost twice more than that of BHA and ascorbic acid (35.6 and $39.9 \%$ scavenging, respectively) [44]. In addition, two compounds (physocalycoside forsythoside $B$ ) isolated from the aerial parts of Phlomis physocalyx exhibited DPPH radical scavenging activity with $\mathrm{IC}_{50}$ of 50 $\mu \mathrm{m}$ and $43 \mu \mathrm{m}$, which appears to be better than Ascorbic acid $\left(\mathrm{IC}_{50}: 112 \mu \mathrm{m}\right)$ [45].

\section{Ferric Reducing Antioxidant Power (FRAP)}

In the definition of an antioxidant, it is stated that antioxidant is a substance that prevents or delay the oxidation of particular substrate, even when they present at low concentrations [46]. This means antioxidants have a wide spectrum actions, including metal chelation, enzymecatalyzed removal of a potential oxidant or inactivation of oxidants acting as reducing agents [47]. Considering the fact that inactivation of an oxidant is a function of antioxidant, therefore it is important to measure reducing ability of the antioxidant substance. For this purpose, we performed two assays to evaluate reducing antioxidant power of the sample: FRAP and CUPRAC.

In FRAP assay, the ability of an antioxidant to reduce ferric-tripiridyltriazine ( $\mathrm{Fe}^{3+}$-TPTZ) to a ferrous form $\left(\mathrm{Fe}^{2+}\right)$, which absorbs light at $593 \mathrm{~nm}$ is measured. Ferric reducing power of the sample is shown in Figure 2A. As can be seen, ethanol extract of the sample showed a ferric reducing power in a concentration dependent manner. However, it is slightly less effective than that of $\alpha$-tocopherol. Trolox exhibited the best reducing potential among them.

\section{Cupric Reducing Antioxidant Capacity (CUPRAC)}

In this assay, copper (II)-neocuproine is reduced to [CU (II)-Nc] reagent by an antioxidant. The result obtained from this assay show that Phlomis pungens has reducing activity similar to $\alpha$-tocopherol. Its activity was increased with increasing concentration (Figure 2B).

Regarding reducing power of Phlomis genus, there are limited number of studies in the literature. In an vivo study, It has been shown that the treatment of diabetic rats with methanolic extract of Phlomis anisodonta (400 mg. $\mathrm{kg}^{-1}$ ) increased ferric reducing power in their liver, as shown with FRAP assay [48].

Although both FRAP and CUPRAC assay measure reducing activity of a compound, CUPRAC assay has more advantageous over FRAP assay. Firstly, CUPRAC assay is capable of measuring thiol-type antioxidants such as glutathione and nonprotein thiols [49]. Secondly, CUPRAC assay is performed at $\mathrm{pH} 7$, which is close to the physiological pH. [50] Thirdly, CUPRAC assay is suitable for measuring reducing power of a wide range of chemical, regardless of chemical type or hydrophilicity [51]. 


\section{Total Antioxidant Activity}

Total antioxidant activity of Phlomis pungens was determined by ferric thiocyanate method. Trolox and $\alpha$-tocopherol were used as reference substance for comparison propose. There was an increase in the absorbance value in control showing that linoleic acid was oxidized and formed peroxides leading the formation of $\mathrm{Fe}^{3+}$ thiocyanate formation, which is measurable at $500 \mathrm{~nm}$ (Figure 3). The result showed that ethanolic extract of the sample $(20 \mu \mathrm{g} / \mathrm{mL})$ caused a reduction in the absorbance and inhibited lipid peroxidation up to 48 hours (Figure 3) The inhibition rate of the substance were $85.3 \%$, $83.1 \%$ and $70.2 \%$ for $\alpha$-tocopherol, $\alpha$-tocopherol and Phlomis pungens, respectively. These results clearly show that ethanolic extract Phlomis pungens is a remarkable potent antioxidant activity.

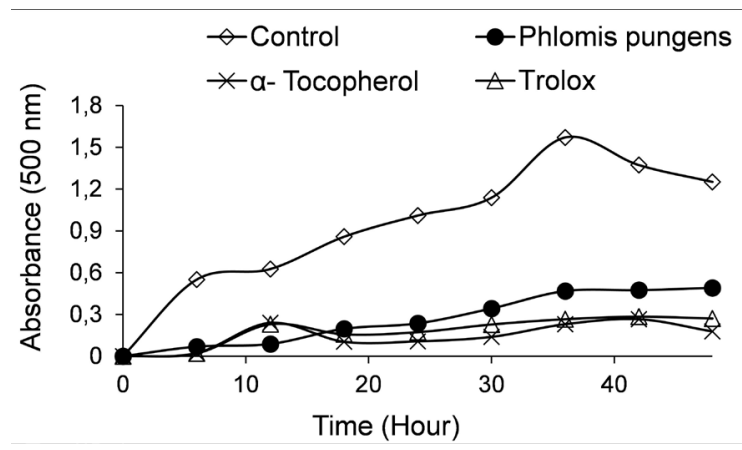

Figure 3. Total antioxidant activity of Phlomis pungens $(20 \mu \mathrm{g} / \mathrm{mL})$ and standard antioxidant compounds.

\section{CONCLUSION}

This study revealed total phenolic and flavonoid content as well as antioxidant properties of Phlomis pungens. According to the data obtained using different in vitro antioxidant assays, ethanolic extract of Phlomis pungens had moderate phenolic and flavonoid content. In addition, the sample studied was found to be effective antioxidant when compared to synthetic antioxidants including BHT, $\alpha$-tocopherol and trolox. The sample was found to be effective for the inhibition of lipid peroxidation in linoleic acid emulsion. Further research could be directed to find out polyphenolic compounds or other components that could be responsible for the antioxidant activity.

\section{References}

1. R.R. Jenkins, Free radical chemistry, Sports Med., 5 (1988) 156-170.

2. J.M. McCord, I. Fridovich, Superoxide dismutase, An enzymic function for erythrocuprein (hemocuprein), J. Biol. Chem., 244 (1969) 6049-6055.

3. U. Bandyopadhyay, D. Das, R.K. Banerjee, Reactive oxygen species: oxidative damage and pathogenesis, Curr. Sci. India, 77 (1999) 658-666.

4. C.A. Papaharalambus, K.K. Griendling, Basic mechanisms of oxidative stress and reactive oxygen species in cardiovascular injury, Trends Cardıovas. Med., 17 (2007)48-54.

5. R. Thanan, S. Oikawa, Y. Hiraku, S. Ohnishi, N. Ma, S. Pinlaor, P. Yongvanit, S. Kawanishi, M. Murata, Oxidative stress and its significant roles in neurodegenerative diseases and cancer, Int. J. Mol. Sci., 16 (2015) 193-217.

6. M. Shang, J.P. Zhao, L. Yang, L. Lin, Oxidative stress and antioxidant status in women with gestational diabetes mellitus diagnosed by IADPSG criteria, Diabetes Res. Clin. Pr., 109 (2015)404-410.

7. D. Bar-Or, R. Bar-Or, L.T. Rael, E.N. Brody, Oxidative stress in severe acute illness, Redox Biol., 4( 2015) 340-345.

8. Y.Z. Fang, S. Yang, G.Y. Wu, Free radicals, antioxidants, and nutrition, Nutrition, 18 (2002) 872-879.

9. M. Antonello, D. Montemurro, M. Bolognesi, M. Di Pascoli, A. Piva, F. Grego, D. Sticchi, L. Giuliani, S. Garbisa, G.P. Rossi, Prevention of hypertension, cardiovascular damage and endothelial dysfunction with green tea extracts, Am. J. Hypertens., 20 (2007) 1321-1328.

10. K. Koariková, M. Ježoviová, J. Keresteš, H. Gbelcová, Z. ura ková, I. Žit anová, Anticancer effect of black tea extract in human cancer cell lines, Springer Plus, 4 (2015) 1-6.

11. P. Cheeke, S. Piacente, W. Oleszek, Anti-inflammatory and anti-arthritic effects of Yucca schidigera: a review, J. Inflamm., 3 (2006) 1-7.

12. A. Branen, Toxicology and biochemistry of butylated hydroxyanisole and butylated hydroxytoluene, J. Am. Oil Chem. Soc., 52 (1975) 59-63.

13. R. Amarowicz, B. Pegg, P. Rahimi-Moghaddam, B. Barl, J.A. Weil, Free-radical scavenging capacity and antioxidant activity of selected plant species from the Canadian prairies, Food Chem., 84 (2004) 551-562.

14. I.L.B. Amor, J. Boubaker, M.B. Sgaier, I. Skandrani, W. Bhouri, A. Neffati, S. Kilani, I. Bouhlel, K. Ghedira, L. Chekir-Ghedira, Phytochemistry and biological activities of Phlomis species, J. Ethnopharmacol., 125 (2009) 183-202.

15. I. Gürbüz, O. Üstün, E. Yesilada, E. Sezik, O. Kutsal, Anti-ulcerogenic activity of some plants used as folk remedy in Turkey, J. Ethnopharmacol., 88 (2003) 9397.

16. F. Demirci, K. Guven, B. Demirci, M. Dadandi, K. Baser, Antibacterial activity of two Phlomis essential oils against food pathogens, Food Control., 19 (2008) 1159-1164. 
17. T.Y. Shin, J.K. Lee, Effect of Phlomis umbrosa root on mast cell-dependent immediate-type allergic reactions by anal therapy, Immunopharm. Immunot. 25 (2003) 73-85.

18. M. Couladis, O. Tzakou, E. Verykokidou, C. Harvala, Screening of some Greek aromatic plants for antioxidant activity, Phytother. Res., 17 (2003) 194195.

19. A.B.Yildirim, F.P. Karakas, A.U. Turker, In vitro antibacterial and antitumor activities of some medicinal plant extracts, growing in Turkey, Asian Pac J. Trop. Med., 6 (2013) 616-624

20. P. Sarkhail, M. Abdollahi, A. Shafiee, Antinociceptive effect of Phlomis olivieri Benth., Phlomis anisodonta Boiss. and Phlomis persica Boiss. total extracts, Pharmacol. Res., 48 (2003) 263-266.

21. A. Bader, T. Tuccinardi, C. Granchi, A. Martinelli, M. Macchia, F. Minutolo, N. De Tommasi, A. Braca, Phenylpropanoids and flavonoids from Phlomis kurdica as inhibitors of human lactate dehydrogenase Phytochemistry, 116 (2015) 262-268.

22. M.X.Li, X.F. Shang, Z.P. Jia, R.X.Zhang, Phytochemical and Biological Studies of Plants from the Genus Phlomis, Chem. Biodivers., 7 (2010) 283-301.

23. I. Gulcin, E. Koksal, M. Elmastas, H.Y. Aboul-Enein, Determination of in vitro antioxidant and radical scavenging activity of Verbascum oreophilum C. Koch var. Joannis (Fam. Scrophulariaceae), Res. J. Biol. Sci. 2 (2007) 372-382.

24. M. Isik, M. Korkmaz, E. Bursal, I. Gulcin, E. Koksal, H. Tohma, Determination of antioxidant properties of Gypsophila bitlisensis bark, Int. J. Pharmacol., 11 (2015) 366-371.

25. J.A. Ross C.M. Kasum, Dietary flavonoids: Bioavailability, metabolic effects, and safety. Annu. Rev. Nutr., 22 (2002) 19-34.

26. M.S. Blois, Antioxidant determinations by the use of a stable free radical, Nature, 181 (1958). 1199-1200.

27. H. Tohma, E. Köksal, Ö. Kılıç, Y. Alan, M.A. Yılmaz, I. Gülçin, E. Bursal, S.H. Alwasel, RP-HPLC/MS/MS analysis of the phenolic compounds, antioxidant and antimicrobial activities of Salvia L. species, Antioxidants, 5 (2016) 38.

28. İ. Gülçin, M. Elmastaş, H.Y. Aboul-Enein, Antioxidant activity of clove oil-A powerful antioxidant source, Arab. J. Chem., 5 (2012). 489-499.

29. R. Apak, K. Güçlü, M. Özyürek, S.E. Karademir, Novel total antioxidant capacity index for dietary polyphenols and vitamins $C$ and $E$, using their cupric ion reducing capability in the presence of neocuproine: CUPRAC method, J. Agr. Food Chem. 52 (2004) 7970-81.

30. E. Bursal, , E. Köksal, İ. Gülçin, G. Bilsel, A.C. Gören, Antioxidant activity and polyphenol content of cherry stem (Cerasus avium L.) determined by LC-MS/MS Food Res. Int., 51 (2013) 66-74.

31. M. Sobeh, N.Z. Mamadalieva, T. Mohamed, S. Krstin, F.S. Youssef, M.L. Ashour, S.S. Azimova, M. Wink Chemical profiling of Phlomis thapsoides (Lamiaceae) and in vitro testing of its biological activitie, Med. Chem. Res., 25 (2016) 2304-2315.

32. C. Sarikurkcu, M.C. Uren, B. Tepe, M. Cengiz, M.S. Kocak, Phlomis armeniaca: Phenolic compounds, enzyme inhibitory and antioxidant activities, Ind Crop. Prod., 78 (2015) 95-101.
33. Y. Zhang, Z.Z. Wang, Phenolic composition and antioxidant activities of two Phlomis species: A correlation study, C. R. Biol., 332 (2009) 816-826.

34. C. Sarikurkcu, M.C. Uren, B. Tepe, M. Cengiz,M.S. Kocak, Phenolic content, enzyme inhibitory and antioxidative activity potentials of Phlomis nissolii and $P$. pungens var. pungens, Ind. Crop. Prod., 62 (2014) 333-340.

35. 35. C. Yu, Z. Wang, S.J. Tan, Q. Wang, C.Y. Zhou, X. Kang, S. Zhao, S. Liu, H.J. Fu, Z. Yu, A. Peng, Chronic kidney disease induced intestinal mucosal barrier damage associated with intestinal oxidative stress injury, Gastroent. Res. Pract., 2016.

36. B. Bukowska, P. Sicinska, A. Pajak, A. Koceva-Chyla, T. Pietras, A. Pszczolkowska, P. Gorski, M. Koter-Michalak, Oxidative stress and damage to erythrocytes in patients with chronic obstructive pulmonary diseasechanges in ATPase and acetylcholinesterase activity, Biochem. Cell Biol., 93 (2015) 574-580.

37. C. Pereira, D. Gracio, J.P. Teixeira, F. Magro, Oxidative stress and dna damage: implications in inflammatory bowel disease, Inflamm. Bowel. Dis., 21 (2015) 24032417.

38. Y. Yang, Y. Sun, W. Yi, Y. Li, C.X. Fan, Z.L. Xin, S. Jiang, S.Y. Di, Y. Qu, R.J. Reiter, D.H. Yi, A review of melatonin as a suitable antioxidant against myocardial ischemiareperfusion injury and clinical heart diseases, J. Pineal. Res., 57 (2014) 357-366.

39. T.M. Vance, Y. Wang, L.J. Su, E.T.H. Fontham, S.E. Steck, L. Arab, J.T. Bensen, J.L. Mohler, M.H. Chen, O.K. Chun, Dietary total antioxidant capacity is inversely associated with prostate cancer aggressiveness in a population-based study, Nutr. Cancer., 68 (2016) 214224.

40. S.R. Shan, X.M. Huang, M.X. Zhang, Y.H. Shi, Anticancer and antioxidant properties of phenolics isolated from Toona sinensis a juss acetone leaf extract, Trop. J. Pharm. Res., 15 (2016) 1205-1213.

41. O. Tusevski, A. Kostovska, A. Iloska, L. Trajkovska, S.G. Simic, Phenolic production and antioxidant properties of some Macedonian medicinal plants, Cent. Eur. J. Biol., 9 (2014) 888-900.

42. I. Gulcin, M. Oktay, E. Koksal, H. Serbetci, S. Beydemir, O.I. Kufrevioglu, Antioxidant and radical scavenging activities of uric acid, Asian J. Chem., 20 (2008) 2079-2090.

43. A. Delazar, A. Sabzevari, M. Mojarrab, H. Nazemiyeh, S. Esnaashari, L. Nahar, S.M. Razavi, S.D. Sarker, Freeradical-scavenging principles from Phlomis caucasica, J. Nat. Med., 62 (2008) 464.

44. U.S. Harput, I. Çaliş, I. Saraco lu, A.A. Dönmez, A. Nagatsu, Secondary metabolites from Phlomis syriaca and their antioxidant activities, Turk. J. Chem., 30 (2006) 383-390.

45. T. Ersoz, K.I. Alipieva, F.N. Yalcin, P. Akbay, N. Handjieva, A.A. Donmez, S. Popov, I. Calis, Physocalycoside, a new phenylethanoid glycoside from Phlomis physocalyx Hub.-Mor, Z. Naturforsch C., 58 (2003) 471-476.

46. B. Halliwell, J.M. Gutteridge, Free radicals in biology and medicine, Oxford University Press, USA, (2015)

47. I.F.F. Benzie, J.J. Strain, The ferric reducing ability of plasma (FRAP) as a measure of "antioxidant power": The FRAP assay, Anal. Biochem., 239 (1996) 70-76. 
48. P. Sarkhail, S. Rahmampour, S. Fadyevatan, A. Mohammadirad, G. Dehghan, G. Amin, A. Shafiee, M. Abdollahi, Antidiabetic effect of Phlomis anisodonta: Effects on hepatic cells lipid peroxidation and antioxidant enzymes in experimental diabetes, Pharmacol. Res., 56 (2007) 261-266.

49. N.Gungor, M. Ozyurek, K. Guclu, S.D. Cekic, R. Apak, Comparative evaluation of antioxidant capacities of thiol-based antioxidants measured by different in vitro methods, Talanta, 83 (2011) 1650-1658.
50. R. Apak, K. Guclu, M. Ozyurek, S.E. Karademir, M. Altun, Total antioxidant capacity assay of human serum using copper(II)-neocuproine as chromogenic oxidant: the CUPRAC method, Free Radical Res., 39 (2005) 949-961.

51. I. Gulcin, E. Bursal, M.H. Sehitoglu, M. Bilsel, A.C. Goren, Polyphenol contents and antioxidant activity of Iyophilized aqueous extract of propolis from Erzurum, Turkey, Food Chem. Toxicol., 48 (2010) 2227-2238. 
